\title{
APPLICATION OF NITROGEN FERTILIZERS AND ITS EFFECT ON TIMELINESS OF FERTILIZERS DECOMPOSITION RESULTING IN LOST OF NITROGEN THROUGH NITROUS OXIDE EMISSIONS FROM SOIL
}

\author{
Koloman Krištof ${ }^{1}$, Tomáš Šima ${ }^{1}$, Ladislav Nozdrovický ${ }^{1}$, \\ Ján Jobbágy ${ }^{1}$, Jan Mareček², Vlastimil Slaný ${ }^{2}$
}

\begin{abstract}
${ }^{1}$ Department of Machines and Production Biosystems, Faculty of Engineering, Slovak University of Agriculture in Nitra, Tr. A. Hlinku 2, 94976 Nitra, Slovakia

${ }^{2}$ Department of Agricultural, Food and Environmental Engineering, Faculty of AgriSciences, Mendel Univeresity in Brno, Zemědělská 1, 61300 Brno, Czech Republic
\end{abstract}

\begin{abstract}
KRIŠTOF KOLOMAN, ŠIMA TOMÁŠ, NOZDROVICKÝ LADISLAV, JOBBÁGY JÁN, MAREČEK JAN, SLANÝ VLASTIMIL. 2018. Application of Nitrogen Fertilizers and its Effect on Timeliness of Fertilizers Decomposition Resulting in Lost of Nitrogen Through Nitrous Oxide Emissions from Soil. Acta Universitatis Agriculturae et Silviculturae Mendelianae Brunensis, 66(3): 691-700.

Fertilizers are an important tool to maintain soil fertility and as an enhancement for the efficient crop production. The system of fertilizers application affects the final dose and commonly causes local overdosing or insuficient spatial distribution of fertilizers which are a very important source of nitrous oxide emissions $\left(\mathrm{N}_{2} \mathrm{O}\right)$ from the soil into the atmospher observation of such phenomenon are among the key factors defining environmental impacts of agriculture. A study was conducted to observe the effect of application dose of fertilizer on $\mathrm{N}_{2} \mathrm{O}$ emission from the soil. CAN (Calcium ammonium nitrate - consist of $27 \%$ nitrogen) was spread by a fertiliser spreader Kuhn Axera 1102 H-EMC aggregated with a tractor John Deere 6150 M. Incorporation of fertilizer into the soil was done by power harrow Pöttinger Lion 302. The application dose was set at 0, 100, 200 and $300 \mathrm{~kg}$. $\mathrm{ha}^{-1}$ while monitoring points were selected at the base of this application doses in respective places. Measurements were conducted at time intervals 7, 14, 21 and 28 days after fertiliser application and following incorporation. Nitrous oxide emissions were measured by field gas monitor set INNOVA consisting of a photoacoustic gas monitor INNOVA 1412 and a multipoint sampler INNOVA 1309. Statistically significant differences was found among time intervals and among the application dose ( $p>0.05)$. It was observed that the application dose of selected fertilizers has the direct effect on nitrous oxide $\left(\mathrm{N}_{2} \mathrm{O}\right)$ emissions released from soil into the atmosphere. An increase of greenhouse gas emissions was observed in range from 0.83 to $152.33 \%$. It can be concluded that the local overdose of fertilizers negatively affects environmental impact of agricultural practices at greenhouse gas emissions (GHGs).
\end{abstract}

Keywords: greenhouse gas emissions, nitrous oxide, fertiliser, fertiliser spreader, application dose

\section{INTRODUCTION}

As Ambus et al. (2011) stated, nitrogen is among the essential elements for plant growth, and is supplied to plants by fertilisers as it was further emphasised by Kajanovičová et al. (2011). It was proven, in later studies, that nitrogen dynamics directly affects cropping parameters such as: crop growth, fertility of soils, potential pollution problems (e.g. $\mathrm{NH}_{3}$ volatilization), acidification of soils, increasing of $\mathrm{NO}_{3}$ - content in drinking water, eutrophication of 
surface water and more importantelly the emissions of the greenhouse gas $\mathrm{N}_{2} \mathrm{O}$ (Ludwig et al., 2011). Mio et al. (2011) have also reported that nitrogen overapplication $(\mathrm{N})$ is commonly observed in intensive agriculture practices in many regions, and current $\mathrm{N}$-uptake efficiency was observed to be at level 28.3, 28.2 and $26.1 \%$ for rice, wheat and maize, respectively. Less than $20 \%$ of $\mathrm{N}$-uptake efficiency was observed in intensive agricultural regions, orchards as well as in vegetable crops production.

Agriculture contributes to the increase in atmospheric $\mathrm{N}_{2} \mathrm{O}$ and it was accounted as $24 \%$ of global annual emissions (IPCC, 2007a; IPCC, 2007b; IPCC, 2014). According to Loubet et al. (2011) and Ranucci et al. (2011) is nitrous oxide $\left(\mathrm{N}_{2} \mathrm{O}\right)$ considered as the most important greenhouse gas which contributes up to $6 \%$ to global warming. Besides, its direct affects on stratospheric ozone layer was observed and reported by Willianms et al. (1992) and later on by Ravishankara et al. (2009).

It was pointed out as a result of the studies conducted by Skiba et al. (1993) and Ambus et al. (2006) that nitrous oxide emissions released from soils are responsible for $\mathrm{N}$ loss from the ecosystem and is caused by nitrification and denitrification processes in soils. Those conclusions was later expanded and supported at different levels by Jiang-Gang et al. (2007) and later on by Senbayram et al. (2012). In addition it was concluded by Van Cleemput and Samater (1996) that the chemodenitrification at low level of $\mathrm{pH}(<5.5)$ was considered as influencing factor as well.

In subsequent studies by Skiba et al. (1997), Skiba and Smith (2000) and Ruser et al. (2001) it was proven that the major $\mathrm{N}_{2} \mathrm{O}$ source is denitrification. It was also concluded that application of high dose of nitrogen fertiliser resulted in the increase of concerns regarding to the $\mathrm{N}_{2} \mathrm{O}$ emissions from intensively farmed fields (Zhu et al., 2011; He et al., 2009; Pang et al., 2009; Lin et al., 2010; Šima, 2014). Although intensive research conducted by various researchers (e.g. Eichner, 1990; Bouwman, 1996; Verma et al., 2006; Jones et al., 2007; He et al., 2009; Pang et al., 2009; Lin et al., 2010, Mapanda et al., 2011 ) indicated that $\mathrm{N}_{2} \mathrm{O}$ emissions from the soil is increasing with the amount of nitrogen fertiliser however there is still a lack of data sets for intensive systems according to fertilisers as it was pointed out by Pfab et al. (2012). In compiled data sets provided by Skiba et al. (2001) and later on by Šima (2014),
Šima et al. (2014a), Šima et al. (2014b) it was concluded that increasing of $\mathrm{N}_{2} \mathrm{O}$ emissions was caused by significant increase of rates of $\mathrm{N}$ added.

A nitrogen form effect on soil respiration was observed by Ramirez et al. (2010). In mentioned study it was tested how different forms of nitrogen (N) amendments affect microbial respiration rates by adding six different forms of nitrogen to three different soil types. It was concluded that all inorganic forms of nitrogen led to various effects: net reduction in microbial respiration and the magnitude of the observed response (<60\%) was consistent across all soils. Moreover negative correlation with nitrogen concentration was observed. Urea also reduced respiration rates in nearly all cases however this effect effect was weakened by the input of labile organic carbon which was associated. In addition, the decrease in respiration was observed regardless of soil type, the specific $\mathrm{N}$ counter ion, $\mathrm{N}$ added as $\mathrm{NH}_{4}+$ or $\mathrm{NO}_{3}-$, or the effects of $\mathrm{N}$ form on soil $\mathrm{pH}$. At the base of these observations it was suggested that decrease in respiration rates were mainly a direct result of the increase in soil nitrogen availability rather than indirect effects caused by the nitrogen form which is added (Ramirez et al., 2010).

The aim of the study was to explore the effect of nitrogen fertiliser application dose on the nitrous oxide emissions released from the soil to the atmosphere in different time intervals.

\section{MATERIALS AND METHODS}

\section{Outline methodology}

The field study was conducted as a randomized experiment in order to meet the defined aim of the study and fullfill its objective. The experimental measurements was conducted on flat land after the harvest of perennial forage crops on a field approximately $40 \mathrm{~km}$ from Nitra city, Slovakia.

The amount of the Calcium ammonium nitrate (CAN containing of nitrogen at $27 \%$ ) fertiliser distributed by the fertiliser spreader Kuhn Axera 1102 H-EMC. Distributed fertilizer was captured by collecting trays representing $1 \mathrm{~m}^{2}$. Sampling points was selected regarding to a different fertiliser application dose at level 0, 100, 200 and $300 \mathrm{~kg}$. $\mathrm{ha}^{-1}$, respectively. Following measurement of nitrous oxide emissions releasing from the soil was

I: Climate conditions and soil characteristics of experimental site station

\begin{tabular}{|c|c|c|c|c|c|}
\hline \multicolumn{6}{|c|}{ Climatic contitions } \\
\hline $\begin{array}{c}\text { Temperature } \\
\text { range }\left({ }^{\circ} \mathrm{C}\right)\end{array}$ & $\begin{array}{c}\text { Average } \\
\text { temperature }\left({ }^{\circ} \mathrm{C}\right)\end{array}$ & $\begin{array}{c}\text { Air humidity range } \\
(\%)\end{array}$ & Air pressure range $(\mathrm{hPa})$ & & Rainfall (mm) \\
\hline $2-15$ & 7.9 & $31-81$ & $980-1100$ & & 0.6 \\
\hline \multicolumn{6}{|c|}{ Soil characteristics } \\
\hline Soil type & $\begin{array}{c}\text { Particles }<0.01 \mathrm{~mm} \\
(\%)\end{array}$ & $\begin{array}{l}\text { Soil organic matter } \\
(\%)\end{array}$ & Humus (\%) & $\mathbf{p} \mathbf{H}_{(\mathrm{H} 2 \mathrm{O})}$ & $\mathbf{p} \mathbf{H}_{(\mathrm{KCl})}$ \\
\hline Sandy-loam & $>20-30$ & $2.95-4.55$ & $3.00-4.90$ & $6.9-7.3$ & $6.5-7.2$ \\
\hline
\end{tabular}


measured by the photoacoustic system INNOVA which consist of photoacoustic gas emission monitor INNOVA 1412 and multipoint gas sampler INNOVA 1309. Time intervals for measuring were selected as 7, 14, 21 and 28 days, after fertilisation. The soil sampling method defined by Šima et al. (2012), Šima (2014), Šima et al. (2014a) and Šima et al. (2014b) was used.

\section{Experimental site}

Experiments were carried out in lands of AGRO Divízia ltd. Selice. The test fields of agricultural company are situated roughly $40 \mathrm{~km}$ from Nitra city, Slovakia. The area is located on $48^{\circ} 05^{\prime} 34.7^{\prime \prime} \mathrm{N}-17^{\circ} 58^{\prime} 38.7^{\prime \prime} \mathrm{E}$. The area is characterised by moderate climate and sandy loam soil (Tab. I).

\section{Fertilizer and machinery}

The double spinning disc fertiliser spreader Kuhn Axera 1102 H-EMC was connected with the tractor John Deere 6150 M. Calcium ammonium nitrate (CAN) was used in the experiment. CAN is formed by a white and grey ammonium nitrate granulates. This granulate is commonly threated by grounded dolomite which decrease the natural acidity of fertiliser. An anticaking technology is used in production of fertilizer which protects its particles against forming of agglometates and keeps fertiliser in favourable form regarding to its application and distribution by centrifugal applicators (CALK AMMONIUM NITRATE, 2010). As a production trademark is used LAD 27 and it is produced by Duslo, a. s. Šal'a, Slovakia. Chemical composition of LAD 27, its grain size distribution and other important parameters was defined by producer. Those parameters were then verified by Šima et al. (2014a) and Šima et al. (2014b). The collecting trays designed at square form $(100 \times 100 \mathrm{~cm})$ representing $1 \mathrm{~m}^{2}$ were used to capture specific amount of distributed fertilizer. Technical parameters of these collecting trays meet the Standard ISO 5690/1.

\section{Soil sampling and gas emissions analysis}

Soil samples were subjected to pedological analysis prior to fertiliser distribution and subsequent analysis were conducted at Department of Soil Science and Geology, Slovak University of Agriculture in Nitra, Slovakia. The results of the analysis are provided in Tab. II.

Measurement of nitrous oxide emissions released from the soil was conducted by using INNOVA measuring system (LumaSense Technologies, Inc., Denmark) which consist of three main parts (Dubeňová et al., 2011). As sampling apparatus serve the sampling probes defined and certified by Šima et al. (2013a; 2013b). The measuring method and its practical verification were described in the previous study on $\mathrm{N}_{2} \mathrm{O}$ (Šima et al., 2012; Šima, 2014; Šima et al., 2014a; Šima et al., 2014b).

\section{Application of fertilizer and experimental conditions}

The fertiliser spreader Kuhn Axera 1102 H-EMC was set according to manufacturer instructions for this type of fertiliser and for the maximum spreading width (for 42 metres). The application dose was set on 0, 100, 200 and $300 \mathrm{~kg} \cdot \mathrm{ha}^{-1}$ which represent 0, 27, 54 and 81 kg.N.ha ${ }^{-1}$, respectively. Non fertilised soil was taken as a controle measurement. The requirements for fertiliser application were in accordance to Standard ISO 5690/1 and STN EN 13739, Part 1 and Part 2. The photoacoustic gas monitoring system INNOVA was used. Soil samples were monitored for 24 hours. A 30 min. time interval for the gas analysis was used.

\section{Data analysis}

The Multifactor Analysis of Variance (MANOVA) was used in order to find out which factor (time and application dose) affects the nitrous oxide flux from soil. The Analysis of Variance (ANOVA) was used to compare the values during measurement of time intervals and application dose. Prior to ANOVA, normality test (Kolmogorov-Smirnov test) and homogeneity test (Levene's test) was conducted. Since obtained P-value was lower than 0.05 a post-hoc LSD test was employed. STATGRAPHICS Centurion XVI.I (Statpoint Technologies, Inc.; Warrenton, Virginia, USA) was used as statistic tool.

\section{RESULTS AND DISCUSSION}

To identify the sampling points for soil analysis with regards to calculated and set application dose was measured trannseversal distribution pattern for used fertilizer spreader (Fig.1, Fig.2 and Fig.3). Such measurements and calculations are not an easy task as it was stated by Olieslagers et al. (1996). It was stated that for site-specific applications it requires a continuous change of several spreader parameters such as orifice position and angular speed of the disc and manipulation of the spreader

II: Pedological specifications and soil samples characteristic

\begin{tabular}{|c|c|c|c|c|c|c|c|}
\hline \multicolumn{8}{|c|}{ General characteristics of soil samples } \\
\hline Soil type & Clay (\%) & Silt (\%) & Sand (\%) & Humus (\%) & $\mathrm{C}_{\mathrm{ox}}(\%)$ & $\mathbf{p} \mathbf{H}_{(\mathrm{H} 2 \mathrm{O})}$ & $\mathbf{p} \mathbf{H}_{(\mathrm{KCl})}$ \\
\hline $\begin{array}{l}\text { Haplic } \\
\text { Luvisol }\end{array}$ & 37.70 & 39.43 & 22.87 & 2.78 & 1.62 & 7.78 & 6.87 \\
\hline \multicolumn{8}{|c|}{ Specified moisture content of analysed samples } \\
\hline \multicolumn{3}{|c|}{ Measurement interval (days) } & 0 & 7 & 14 & 21 & 28 \\
\hline \multicolumn{3}{|c|}{ Moisture content (\% vol) } & $26-28$ & $25-26$ & $23-25$ & $24-26$ & $22-24$ \\
\hline
\end{tabular}


pattern produced by spinning disc fertilizer spreaders. It is important to keep the working width and the shape of the spreader pattern constant for varying fertilizer rates. In our study, relatively stable spread pattern were observed for all of the application doses. These patterns can be described by trend lines $\mathrm{y}=-5.6638 \mathrm{x}+286.12$ $\left(\mathrm{R}^{2}=0.9544\right), \mathrm{y}=-5.9007 \mathrm{x}+293.91\left(\mathrm{R}^{2}=0.9485\right)$ and $\mathrm{y}=-5.7822 \mathrm{x}+290.02\left(\mathrm{R}^{2}=0.956\right)$ for application doses 300, 200 and $100 \mathrm{~kg} \cdot \mathrm{ha}^{-1}$, respectively (Fig. 1, Fig. 2 and Fig. 3). Moreover, to simulate variations of angular velocity of the disc as well as the effects of a changing position of the orifice which referring to the driving direction affect the spreading width and the shape of the distribution pattern. The shape and the width of the distribution pattern are also largely affected by the shape of the orifice. Further analysis showed that utilise site-specifically spreading simply changing the mass flow leading to a fluctuating spreader pattern. It commonly results in large deviations from the intended application rates (Olieslagers et al., 1996).

But subsequently Fulton et al. (2005) conducted a study into distribution pattern variability of granular VRT (variable-rate technology) applicators. This technology appears to be reliable solution however with it own limitation. The results of this study demonstrate potential application errors with VRT and the need for proper calibration to maintain acceptable performance. Further study then demonstrated the need for a VRT equipment testing standard (Fulton et al., 2005).

Spread patterns of the fertiliser (Fig. 1 and Fig. 2) were measured with following record of position. Monitoring points were determined based on the calculated average value (Fig. 3) of the amount of applied fertiliser in the first and second spread pattern line.

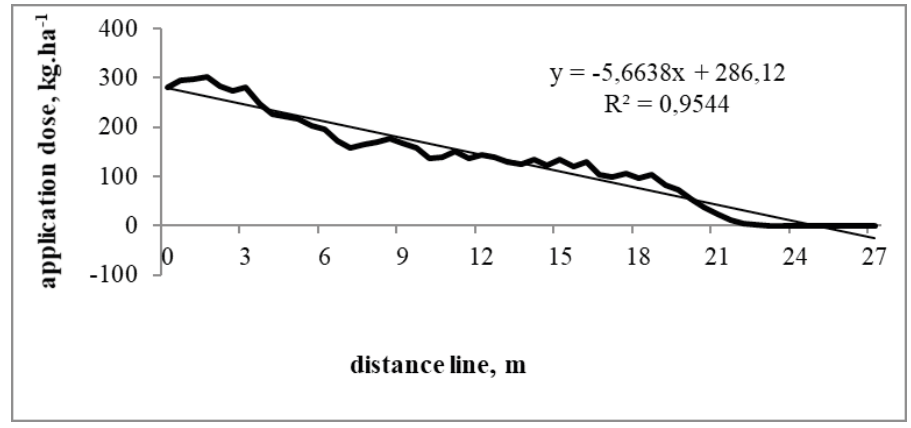

1: First measurement of spreading pattern (application dose $300 \mathrm{~kg} \cdot \mathrm{ha} \mathrm{a}^{-1}$ )

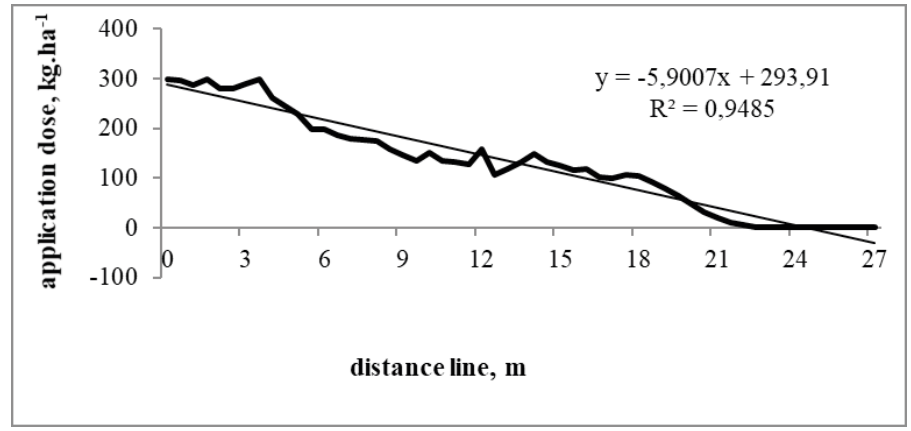

2: Second measurement of spreading pattern (application dose $200 \mathrm{~kg} \cdot \mathrm{ha}^{-1}$ )

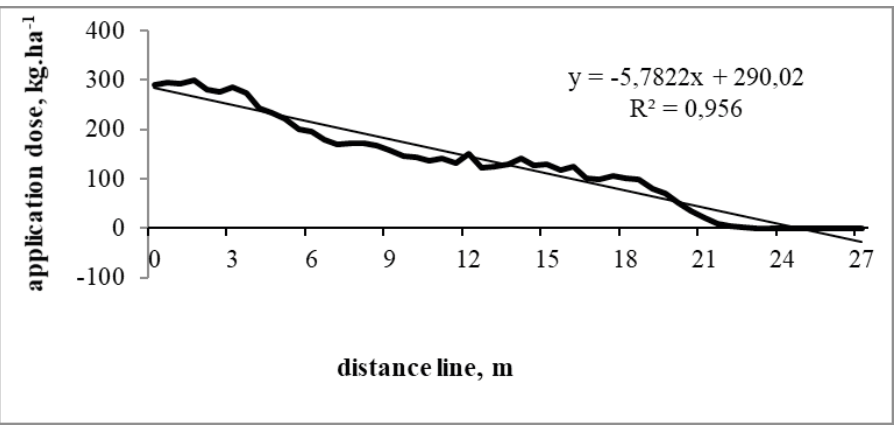

3: Third measurement of spreading pattern (application dose $100 \mathrm{~kg} \cdot \mathrm{ha}^{-1}$ ) 
According to Parish (2003) it is usually assumed that the distribution pattern delivered by walk-behind rotary spreaders is unaffected by rate setting. Thus, rate setting development can be determined independently of pattern setting and effective width. Some professional walk-behind rotary spreaders are using the spiral cone and it is very effective at pattern adjustment and control. However it may perform differently with different flow rates of granular material. A comparative study was conducted on both types of spreaders and different size grades of blank pesticide carrier. There were observed the effect of rate setting on spreader pattern. Severe pattern distortion was documented at very low rate settings and a gradual shift in pattern with high rates. Relatively stable patterns appeared within the range of delivery rates for turf products which are normally used. Moreover, Virk et al. (2013) stated that utilization of spinner-disc spreaders is commonly used for application of blended fertilizers to crop and pasture land. However, it was observed greater non-uniformity disctribution of blended fertilizers due to its nature and varying physical properties of the N, P, and K of its raw constituents. This phenomenon leads to segregation during application. In terms of accuracy and uniformity to meet target prescription rates could pose challenges in variable-rate application of blended fertilizer. Moreover, Macák and Krištof (2016) stated that granulometric structure and moisture of fertilizer have a great influence on fertiliser spreader quality of work while it affect in both ways a distribution patterns and kinematic parameters of distributed fertiliser particles.

The comprehensive output of measured data is shown in Tab. III. According to complete comparison it was determined which of the factors (time and application dose) affects the nitrous oxide emissions from soil into the atmosphere. While it was observed that all three P-values of the Multifactor Analysis of Variance (MANOVA) were lower than 0.05. In this case it means that these factors have a statistically significant effect on nitrous oxide emissions released from soil at $\alpha=0.05$.

Statistically significant differences were found seven days after fertilisation (Table IV). Specifically there was found significant differences in nitrous

III: Nitrous oxide emissions measurement summary statistic ( $n=50)$

\begin{tabular}{|c|c|c|c|c|c|c|c|}
\hline \multirow[b]{2}{*}{ Time, days } & \multirow{2}{*}{$\begin{array}{c}\text { Dose, } \\
\text { kg.ha-1 }\end{array}$} & \multicolumn{6}{|c|}{ Attributes of summary statistics } \\
\hline & & Mean, ppm & $\begin{array}{c}\text { Median, } \\
\text { ppm }\end{array}$ & Min, ppm & Max, ppm & $\begin{array}{c}\text { Range, } \\
\text { ppm }\end{array}$ & s.d., ppm \\
\hline \multirow{4}{*}{7} & 0 & 0.456 & 0.461 & 0.430 & 0.474 & 0.043 & 0.012 \\
\hline & 100 & 0.460 & 0.463 & 0.438 & 0.472 & 0.034 & 0.010 \\
\hline & 200 & 0.464 & 0.469 & 0.436 & 0.484 & 0.048 & 0.013 \\
\hline & 300 & 0.468 & 0.472 & 0.445 & 0.484 & 0.039 & 0.013 \\
\hline \multirow{4}{*}{14} & 0 & 0.447 & 0.452 & 0.413 & 0.473 & 0.060 & 0.020 \\
\hline & 100 & 0.597 & 0.596 & 0.546 & 0.644 & 0.097 & 0.021 \\
\hline & 200 & 0.678 & 0.679 & 0.649 & 0.707 & 0.057 & 0.013 \\
\hline & 300 & 0.793 & 0.804 & 0.748 & 0.830 & 0.082 & 0.023 \\
\hline \multirow{4}{*}{21} & 0 & 0.449 & 0.450 & 0.427 & 0.463 & 0.035 & 0.007 \\
\hline & 100 & 0.838 & 0.833 & 0.816 & 0.878 & 0.062 & 0.015 \\
\hline & 200 & 1.013 & 1.015 & 0.968 & 1.039 & 0.071 & 0.018 \\
\hline & 300 & 1.133 & 1.138 & 1.096 & 1.152 & 0.055 & 0.015 \\
\hline \multirow{4}{*}{28} & 0 & 0.456 & 0.456 & 0.441 & 0.468 & 0.027 & 0.006 \\
\hline & 100 & 0.772 & 0.772 & 0.733 & 0.802 & 0.068 & 0.017 \\
\hline & 200 & 0.851 & 0.852 & 0.838 & 0.860 & 0.021 & 0.005 \\
\hline & 300 & 1.002 & 1.002 & 0.996 & 1.009 & 0.012 & 0.003 \\
\hline
\end{tabular}

IV: Nitrous oxide emissions released from the soil test LSD $(n=50)$

\begin{tabular}{|c|c|c|c|c|}
\hline \multirow{2}{*}{ Time, days } & \multicolumn{4}{|c|}{ Application dose, kg.ha-1 } \\
\hline & 0 & 100 & 200 & 300 \\
\hline 7 & $0.4568^{a}{ }_{t}$ & $0.4606^{a b}{ }_{t}$ & $0.4644^{b c}{ }_{t}$ & $0.4686_{t}^{c}$ \\
\hline 14 & $0.4472^{\mathrm{a}}{ }_{\mathrm{u}}$ & $0.5973^{b}{ }_{u}$ & $0.6782_{u}^{c}$ & $0.7937^{d}$ \\
\hline 21 & $0.4491^{\mathrm{a}}{ }_{\mathrm{u}}$ & $0.8385^{b}{ }_{z}$ & $1.0131_{\mathrm{z}}^{\mathrm{c}}$ & $1.1332^{\mathrm{d}}$ \\
\hline 28 & $0.4561^{\mathrm{a}}$ & $0.7723^{b}$ & $0.8512^{\mathrm{c}}$ & $1.0021^{\mathrm{d}}$ \\
\hline
\end{tabular}

Data of nitrous oxide emissions in ppm; Different letters (a,b,c,d) mean the effect of the application dose and (t, u, $\mathrm{v}$, $\mathrm{z}$ ) mean the effect of the time (significantly different $\mathrm{p}<0.05, \mathrm{n}=50$. 
oxide emissions in selected monitoring points with application dose of fertiliser at 0 and $200 \mathrm{~kg} \cdot \mathrm{ha}^{-1}$, 0 and $300 \mathrm{~kg} \cdot \mathrm{ha}^{-1}$, and 100 and $300 \mathrm{~kg} \cdot \mathrm{ha}^{-1}$. These observations are even more interesting in the frame of other possible nutrient losses e.g. N leaching as it was emphasised by Šima et al. (2014a) and Šima et al. (2014b). Moreover, Fang et al. (2006) conducted an experiment with two soil moisture by four $\mathrm{N}$ treatments. The study was conducted to investigate the effects of $\mathrm{N}$ application doses and soil moisture on soil $\mathrm{N}$ dynamics. As other factors, crop yield, $\mathrm{N}$ uptake and use efficiency in an intensive double cropping system of wheat and maize were used. It was observed that $\mathrm{N}$ rates above $200 \mathrm{~kg} . \mathrm{N}^{-h a^{-1}}$ did not result in significant increase of crop yield of both wheat and maize. In the $0-100 \mathrm{~cm}$ soil profiles, nitrogen application doses affected little on ammonium-N content. It was stated the key to reduce $\mathrm{N}$ leaching and maintain the crop yield is to avoid excess water leakage through controlled irrigation and matching $\mathrm{N}$ application to crop $\mathrm{N}$ demand. However, knowledge of crop water and $\mathrm{N}$ demand and soil $\mathrm{N}$ dynamics is required for such management while these factors are changing with climate variability in term of spatial and temporal. Models and simulations can capture those interactions. These models and simulations are considered as a powerful tool to assist in the future optimization of $\mathrm{N}$ and irrigation managements (Fang et al., 2006).

Differences in nitrous oxide flux were not found (Tab. IV) in selected monitoring points with the application dose 0 and $100 \mathrm{~kg} \cdot \mathrm{ha}^{-1}$, 100 and $200 \mathrm{~kg} \cdot \mathrm{ha}^{-1}$, and 200 and $300 \mathrm{~kg} \cdot \mathrm{ha}^{-1}$. However, statistically significant differences were observed in 14, 21 and 28 days after fertilisation (Tab. IV). These differences were proven also for all selected monitoring points with the fertiliser application doses $0,100,200$ and $300 \mathrm{~kg} \cdot \mathrm{ha}^{-1}$.

It can be concluded that there is an effect of the application dose of fertilizer on nitrous oxide emissions from the soil to the atmosphere. Increase of the fertiliser application dose leads to the significant increase of the nitrous oxide emissions. These conclusions corresponds with results obtained by other researchers, however at different level of fertilizer (e.g. Eichner, 1990; Bouwman, 1996; Verma et al. 2006; Jones et al. 2007; He et al. 2009; Pang et al. 2009; Lin et al. 2010; Mapanda et al. 2011; Šima, 2014; Šima et al. 2014a; Šima et al. 2014b).

As an aswer to fertilizer application dose effect on nitrous oxide emission and interaction with local overdosing the variable application dose may become more benefitial (Šima et al., 2014a; Šima et al., 2014b). As Walters et al. (2000) stated an accurate basis for variable rate application can be provided by grid sampling. However, it was emphasised also that other approaches may be more economical due to the cost and labor requirements. The management zones can be defined by farmer as high, medium, and low productivity zones by utilising of aerial photographs as a template. It was confirmed by cluster analysis that management zones represent different suites of soil characteristics. Trends indicated by management zones were followed by soil organic matter (SOM), clay, nitrate, potassium, zinc, conductivity and corn yield in field one. However, in the second field, the highest values for these parameters were observed for medium productivity zone. For identification of different management zones by Farmer appear to be effective. However, the need of ground truthing prior to development of accurate VRT maps from the zones was also suggested by Walters et al. (2000).

Ding et al. (2010) conducted a study to understand the effects of nitrogen fertilization on soil respiration for fluovo-aquic loamy soil. It was observed that soil temperature and also soil moisture significantlly affect the soil $\mathrm{CO}_{2}$ efflux during the maize growth season. However, it was distinguished the opposite effect of soil moisture below and above the optimum values. There was a significant interdependence between soil temperature and soil moisture in the presence of maize plants in the effect on soil $\mathrm{CO}_{2}$ efflux. However, in a comparative study conducted by Krištof et al. (2014) was observed a direct effect of tillage on $\mathrm{CO}_{2}$ emissions from soil. Therefore further incorporation of fertilizers may lead to indirect elevation of $\mathrm{CO}_{2}$ emissions. In addition it was found that cumulative seasonal soil $\mathrm{CO}_{2}$ emissions were $7.4 \%$ lower in the $\mathrm{NL}$ (low nitrogen) and $\mathrm{NH}$ (high nitrogen) treatments than in the N0 treatment (lowest nitrogen). These results indicate that $\mathrm{N}$ fertilization depress soil respiration marginally and significantly. Finally, $\mathrm{N}$ application doses, however, did not exhibit any effects. The results of study then suggesting that the soil respiration affected by $\mathrm{N}$ fertilization mainly depend on the easily decomposed organic carbon in soil and its concentration. Moreover, soil respiration in the planted soils can be possibly reduced by $\mathrm{N}$ fertilization when $\mathrm{N}$ released from the decomposition of native soil organic carbon roughly met the demand for maize growth (Ding et al., 2010).

As it is showed in Fig. 4 the time period significantly affects $\mathrm{N}_{2} \mathrm{O}$ emissions from soil. The highest values of nitrous oxide emissions were observed in $21^{\text {st }}$ days after fertilisation. Subsequently, at $28^{\text {th }}$ day a significant decrease of soil emissions measurements was observed. At the same time, this amount of nitrous oxide emissions was observed to be lower than the maximum value at $21^{\text {st }}$ day of measurement. However it remains to be higher than at $14^{\text {th }}$ day of measurent. As it was pointed out the time is one of fundamental aspects in case of crop growth and both short term and long term. Maio et al. (2011) stated that an organic fertilizers seems to be more that suitable for improvement of soil fertility and quality. However it can also lead to more nitrate leaching within the scope of long-term application at high rates, and accumulation of $\mathrm{P}$ as well if will not 


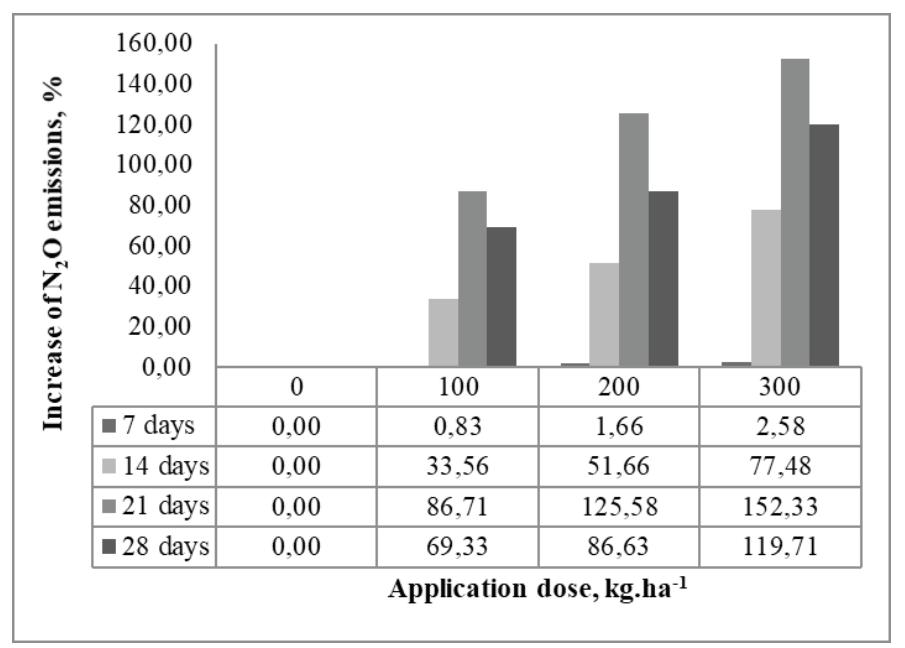

4: Nitrous oxide emissions from soil in contrast with different fertiliser aplication dose

managed with carefull apporoach. The mineral and organic fertilizers can overcome the disadvantages of applying single source of fertilizers however; well-managed combination has to be applied. These kinds of well-managed practices allows then sustainably achieve higher crop yields through the improvement of soil fertility, alleviation of soil acidification, and increase in nutrient efficiency usage in comparison with utilisation of chemical fertilizers only. In addition it can be pointed out that the temporal diversity using crop rotation strategies can result in increased crop yield in comparison with continuous cropping. Moreover, legume-based cropping systems can reduce carbon and nitrogen losses. Despite the fact that $\mathrm{N}$ fertilisation affect the crop yield with positive response it may vary from year to year significantly due to variation in weather conditions. In addition original supply of nitrogen which is then commonly adopted prescriptive approach to nitrogen management needs to be replaced. As an alternative is considered the utilisation of in-season responsive management approach however more complicated while it is based on diagnosis of crop growth, nitrogen storage in soil and following demands of loss replace (Miao et al., 2011).

\section{CONCLUSION}

The aim of the study was to observe the effect of nitrogen fertiliser application dose on nitrous oxide emissions released from soil into the atmosphere. It was observed that $\mathrm{N}_{2} \mathrm{O}$ emissions released from the soil to the atmosphere showed a dependency on the fertiliser application dose. Increase in application dose leads to an increase of $\mathrm{N}_{2} \mathrm{O}$ emissions. Specifically, there were found statistically significant differences even in time range of seven days after fertilisation. These differences were observed in case of comparison doses: 200 and 0 kg.ha ${ }^{-1}, 300$ and 0 kg.ha-1, and 300 and $100 \mathrm{~kg} \cdot \mathrm{ha}^{-1}$. However, comparison of doses 100 and 0 kg.ha-, 200 and $100 \mathrm{~kg}^{-1} \mathrm{ha}^{-1}$, and 300 and $200 \mathrm{~kg} \cdot \mathrm{ha}^{-1}$ did not reveal any differences in nitrous oxide emissions from the soil. In time scales 14, 21 and $28^{\text {th }}$ days

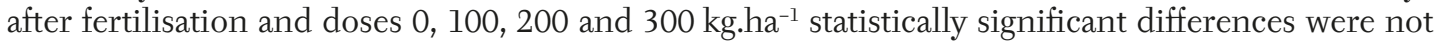
found. However a significant effect of time period on $\mathrm{N}_{2} \mathrm{O}$ emissions released from soil was found. The highest values of $\mathrm{N}_{2} \mathrm{O}$ emissions were observed at $21^{\text {st }}$ day after fertilisation. Following decrease in values of $\mathrm{N}_{2} \mathrm{O}$ emissions were observed at $28^{\text {th }}$ day after fertilisation. The results obtained show the increase of nitrous oxide emissions released from the soil to the atmosphere with increasing the nitrogen fertiliser application dose. It can be concluded that extensive nitrogen losses through $\mathrm{N}_{2} \mathrm{O}$ emissions are critical in first three weeks after fertilisation. In this time period it grews constantly till the forth weeks when the decrease will show up. These data sets then suggest that fertilisation has a great effect on nitrogen release from soil into the atmosphere. Therefore, a carefull management have to be imployed in order to secure a stabile crop production along with environmental friendly production system.

\section{Acknowledgement}

The paper reflects the results obtained within the research project VEGA 1/0718/17: Study about the effect of technological parameters of the surface coating in agricultural and forestry techniques for qualitative parameters, safety and environmental acceptability. 


\section{REFERENCES}

AMBUS, P., SKIBA, U., BUTTERBACH-BAHL, K. and SUTTON, M. 2011. Reactive nitrogen and greenhouse gas flux interactions in terrestial ecosystems. Plant and Soil, 343(1-2): 1-3.

AMBUS, P., ZECHMEISTER-BOLTENSTERN, S. and BUTTERBACH-BAHL, K. 2006. Sources of nitrous oxide emitted from European forrest soils. Biogeosciences, 3: 135-145.

BOUWMAN, A. F. 1996. Direct emissions of nitrous oxide from agricultural soils. Nutrient Cycling in Agroecosystems, 46(1): 53-70.

DUSLO. 2010. Calk ammonium nitrate - Properties of CAN 27 fertilizer. DUSLO. [Online]. Available at: www.duslo.sk [Accessed: 2016, October 25].

DING, W., YU, H., CAI, Z., HAN, F. and XU, Z. 2010. Responses of soil respiration to N fertilization in a loamy soil under maize cultivation. Geoderma, 155(3-4): 381-389.

DUBEŇOVÁ, M., GÁLIK, R. and MIHINA, Š. 2011. Interim results of monitoring of greenhouse gases emissions in the pigs housing [in Slovak: Priebežné výsledky monitorovania emisiísklenníkových plynov v objektoch pre ošípané]. In: Mendeltech International 2011: Proceedings of scientific papers. Brno: Mendel University in Brno, pp. 3843.

EICHNER, M. J. 1990. Nitrous oxide emissions from fertilized soils: Summary of available data. Journal of Environmental Quality, 19: 272-280.

FANG, Q., YU, Q., WANG, E., CHEN, Y., ZHANG, G., WANG, J. and LI, L. 2006. Soil nitrate accumulation, leaching and crop nitrogen use as influenced by fertilization and irrigation in an intensive wheat-maize double cropping system in the North China Plain. Plant and Soil, 284(1-2): 335-350.

FULTON, J. P., SHEARER, S. A., HIGGINS, S. F., HANCOCK, D. W. and STOMBAUGH, T. S. 2005. Distribution pattern variability of granular VRT applicators. Transactions of the American Society of Agricultural Engineers, 48(6): 2053-2064.

HE, F. F., JIANG, R. F., CHEN, Q., ZHANG, F. S. and SU, F. 2009. Nitrous oxide emissions from an intensively managed greenhouse vegetable cropping system in Northern China. Environmental Pollution, 157: 1666-1672.

LUMASENSE TECHNOLOGIES. 2007. Innova devices. LumaSense Technologies. [Online]. Available at: www. lumasenseinc.com [Accessed: 2016, October 25].

IPCC. 2007a. Climate Change 2007: Impacts, Adaptation and Vulnerability. Working Group II Contribution to the Fourth Assessment Report of the Intergovernmental Panel on Climate Change, Cambridge, United Kingdom and New York, NY, USA: Cambridge University Press.

IPCC. 2007b. Climate Change 2007: Synthesis Report. Contribution of Working Groups I, II and III to the Fourth Assessment Report of the Intergovernmental Panel on Climate Change IPCC. Geneva, Switzerland: IPCC.

IPCC. 2014. Climate Change 2014: Synthesis Report. Climate Change 2014: Synthesis Report. Contribution of Working Groups I, II and III to the Fifth Assessment Report of the Intergovernmental Panel on Climate Change. Geneva, Switzerland: IPCC.

JIANG-GANG, H., YONG-LI, Z., HONG-YING, B., DONG, Q., JIN-YU, C. and CHUN-DU, W. 2007. N2O emissions under different moisture and temperature regimes. Bulletin of Environmental Contamination and Toxicology, 78: 284-287.

JONES, S. K., REES, R. M., SKIBA, U. M. and BALL, B. C. 2007. Influence of organic and mineral N fertiliser on N2O fluxes from a temperate grassland. Agriculture, Ecosystems $\odot$ Environment, 121(1-2): 74-83.

KAJANOVIČOVÁ, I., LOŽEK, O., SLAMKA, P. and VÁRADY, T. 2011. Balance of nitrogen in integrated and ecological farming system on soil [in Slovak: Bilancia dusíka v integrovanom a ekologickom systéme hospodárenia na pôde]. Agrochémia, 51(3): 7-11.

KRIŠTOF, K., ŠIMA, T., NOZDROVICKÝ, L. and FINDURA, P. 2014. The effect of soil tillage intensity on carbon dioxide emissions released from soil into the atmosphere. Agronomy Research, 12(1): 115-120.

LIN, S., IQBAL, J., HU, R. G. and FENG, M. L. 2010. N2O emissions from different land uses in mid-subtropical China. Agriculture, Ecosystems $\sigma$ Environment, 136: 40-48.

LOUBET, B., LAVILLE, P., LEHUGER, S., LARMANOU, E., FLÉCHARD, C., MASCHER, N., GENERMONT, S., ROCHE, R., FERRARA, R. M., STELLA, P., PERSONNE, E., DURAND, B., DECUQ, C., FLURA, D., MASSON, S., FANUCCI, O., RAMPON, J.-N., SIEMENS, J., KINDLER, R., GABRIELLE, B., SCHRUMPF, M. and CELLIER, P. 2011. Carbon, nitrogen and Greenhouse gases budgets over a four years crop rotation in northern France. Plant and Soil, 343(1-2): 109-137.

LUDWIG, B., JÄGER, N., PRIESACK, E. and FLESSA, H. 2011. Application of the DNDC model to predict $\mathrm{N} 2 \mathrm{O}$ emissions from sandy arable soils with differing fertilization in a long-term experiment. Journal of Plant Nutrition and Soil Science, 174: 350-358.

MACÁK, M. and KRIŠTOF, K. 2016. The effect of granulometric structure and moisture of fertilizer on its static strength. Research in Agricultural Engineering, 62: S34-S43.

MAPANDA, F., WUTA, M., NYAMANGARA, J. and REES, R. M. 2011. Effects of organic and mineral fertilizer nitrogen on greenhouse gas emissions and plant-captured carbon under maize cropping in Zimbabwe. Plant and Soil, 343(1-2): 67-81. 
MIAO, Y., STEWART, B. A. and ZHANG, F. 2011. Long-term experiments for sustainable nutrient management in China. A review. Agronomy for Sustainable Development, 31(2): 397-414.

OLIESLAGERS, R., RAMON, H. and DE BAERDEMAEKER, J. 1996. Calculation of fertilizer distribution patterns from a spinning disc spreader by means of a simulation model. Journal of Agricultural Engineering Research, 63(2): 137-152.

PANG, X. B., MU, Y. J., LEE, X. Q., FANG, S. X., YUAN, J. and HUANG, D. K., 2009. Nitric oxides and nitrous oxide fluxes from typical vegetables cropland in China: Effects of canopy, soil properties and field management. Atmospheric Environment, 43: 2571-2578.

PARISH, R.L. 2002. Rate setting effects on fertilizer spreader distribution patterns. Applied Engineering in Agriculture, 18(3): 301-304.

PFAB, H., PALMER, I., BUEGGER, F., FIEDLER, F., MÜLLER, T. and RUSER, R. 2012. Influence of a nitrification inhibitor and of placed $\mathrm{N}$-fertilization on $\mathrm{N}_{2} \mathrm{O}$ fluxes from a vegetable cropped loamy soil. Agriculture, Ecosystems $\sigma$ Environment, 150: 91-101.

RAMIREZ, K. S., CRAINE, J. M. and FIERER, N. 2010. Nitrogen fertilization inhibits soil microbial respiration regardless of the form of nitrogen applied. Soil Biology and Biochemistry, 42(12): 2336-2338.

RANUCCI, S., BERTOLINI, T., VITALE, L., DI TOMMASI, P., OTTAIANO, L., OLIVA, M., AMATO, U., FIERRO, A. and MAGLIULO, V. 2011. The influence of management and environmental variables on soil N2O emissions in a crop system in Southern Italy. Plant and Soil, 343(1-2): 83-96.

RAVISHANKARA, A. R., DANIEL, J. S. and PORTMANN, R. W. 2009. Nitrous oxide (N2O): the dominant ozone-depleting substance emitted in the $21^{\text {st }}$ century. Science, 326(5949): 123-125.

RUSER, R., FLESSA, H., SCHILLING, R., BEESE, F., MUNCH, J. C. 2001. Effect of crop-specific field management and $\mathrm{N}$ fertilization on $\mathrm{N} 2 \mathrm{O}$ emissions from a fine-loamy soil. Nutrient Cycling in Agroecosystems, 59(2): 177-191.

SENBAYRAM, M., CHEN, R., BUDAI, A., BAKKEN, L. and DITTERT, K. 2012. N2O emissions and the $\mathrm{N} 2 \mathrm{O} /(\mathrm{N} 2 \mathrm{O}+\mathrm{N} 2)$ product ratio of denitrification as controlled by available carbon substrates and nitrate concentrations. Agriculture, Ecosystems $\odot$ Environment, 147: 4-12.

SKIBA, U., SMITH, K. A. and FOWLER, D. 1993. Nitrification and denitrification as sources on nitric oxide and nitrous oxide in a sandy loam soil. Soil Biology and Biochemistry, 25(11): 1527-1536.

SKIBA, U., FOWLER, D. and SMITH, K. A. 1997. Nitric oxide emissions from agricultural soils in temperate and tropical climates: sources, control and mitigation options. Nutrient Cycling in Agroecosystems, 48: 75-90.

SKIBA, U. and SMITH, K. A. 2000. The control of nitrous oxide emissions from agricultural and natural soils. Chemosphere, 2: 379-386.

SKIBA, U., SOZANSKA, M., METCALFE, S. and FOWLER, D. 2001. Spatially disaggregated inventories of soil NO and N2O emissions for Great Britain. Water, Air and Soil Pollution, 1(5-6): 109-118.

ŠIMA, T. 2014. Research of the environmental effects of the fertilizer spreader work quality. PhD thesis. Nitra: SUA in Nitra.

ŠIMA, T., NOZDROVICKÝ, L., KRIŠTOF, K., DUBEŇOVÁ, M., KRUPIČKA, J. and KRÁLIK, S. 2012. Method for measuring of N2O emissions from fertilized soil after the using of fertilizer spreader. Poljoprivredna tehnika, 37: 51-60.

ŠIMA, T., KRIŠTOF, K., DUBEŇOVÁ, M., NOZDROVICKÝ, L., KRUPIČKA, J. and CHYBA, J. 2013 a. Sampling probe for field measurement of emissions reselased from soil into the atmosphere [in Czech: Sonda na polní mérení emisí uvolňovaných z püdy do atmosféry]. Utility pattern No. 25289. Prague: Industrial Property Office, 2013. 2 p.

ŠIMA, T., KRIŠTOF, K., DUBEŇOVÁ, M., NOZDROVICKÝ, L., KRUPIČKA, J. and CHYBA, J. 2013 b. Sampling probe for field measurement of emissions released from soil into the atmosphere [in Czech: Odbèrná sonda na laboratorní méréní emisí uvol'novaných z puidy do atmosféry]. Utility pattern No. 25348, Prague, Industrial Property Office, 2013. 2 p.

ŠIMA, T., NOZDROVICKÝ, L., KRIŠTOF, K., DUBEŇOVÁ, M. and KRUPIČKA, J. 2014a. Impact of the quality of work of fertiliser spreader on nitrous oxide emissions released from soil to the atmosphere. Agronomy Research, 12(1): 171-178.

ŠIMA, T., NOZDROVICKÝ, L., KRIŠTOF, K. and KRUPIČKA, J. 2014b. Impact of the size of nitrogen fertiliser application rate on N2O flux. Research in Agricultural Engineering, 60(1): 24-29.

VAN CLEEMPUT, O. and SAMATER, A. H. 1996. Nitrite in soils: accumulation and role in the formation of gaseous N compounds. Fertilizer Research, 45(1): 81-89.

VERMA, A., TYAGI, L., YADAV, S. and SINGH, S.N. 2006. Temporal changes in $\mathrm{N}_{2} \mathrm{O}$ efflux from cropped and fallow agricultural fields. Agriculture, Ecosystems $\odot$ Environment, 116: 209-215.

VIRK, S. S., MULLENIX, D. K., SHARDA, A., HALL, J. B., WOOD, C. W., FASINA, O. O., MCDONALD, T. P., PATE, G. L. and FULTON, J. P. 2013. Case study: Distribution uniformity of a blended fertilizer applied using a variable-rate spinner-disc spreader. Applied Engineering in Agriculture, 29(5): 627-636.

WALTERS, R.W., JENQ, R. R. and HALL, S. B. 2000. Evaluating farmer defined management zone maps for variable rate fertilizer application. Precision Agriculture, 2(2): 201-215. 
WILLIAMS, E. J., HUTCHINSON, G. L. and FEHSENFELD, F.C. 1992. NOx and $\mathrm{N}_{2} \mathrm{O}$ emissions from soil. Global Biogeochemical Cycles, 6(4): 351-388.

ZHU, T., ZHANG, J. and CAI, Z. 2011. The contribution of nitrogen transformation processes to total N2O emissions from soils used for intensive vegetable cultivation. Plant and Soil, 343(1):313-327. 